\title{
PROBLEMATIKA HAK CIPTA SEBAGAI JAMINAN FIDUSIA DALAM TRANSAKSI KREDIT PERBANKAN DI INDONESIA
}

\author{
Lidwina Tessa Kurnia Prihantiwi \\ E-mail: lidwinatessa70@gmail.com \\ Mahasiswi S1 Fakultas Hukum Universitas Sebelas Maret \\ Pujiyono \\ E-mail: pujifhuns@gmail.com \\ Dosen Fakultas Hukum Universitas Sebelas Maret
}

\begin{abstract}
This article has the main problem with the causes of banks not allowing copyright as a Fiduciary Guarantee in Banking Credit Transactions in Indonesia. Besides, this article aims to find out the solutions that must be done so that copyright can become a Fiduciary Guarantee. This article is empirical legal research and has a descriptive nature. The types of data used are primary and secondary. Data collection techniques used were interviews and literature studies, then the technical analysis used was the deductive method. The results showed that several things cause copyright as a fiduciary guarantee in bank credit transactions not yet allowed by banks. The first cause is regulatory constraints, intellectual property rights assessment constraints such as copyright, constraints according to banking, constraints according to the OJK, constraints on people's evaluation of copyright. From the various causes, the authors also describe solutions to overcome these causes so that there is a bright spot on Copyright Problems as a Fiduciary Guarantee in Banking Credit Transactions.
\end{abstract}

Keywords: Copyright; Fiduciary Guarantee; Banking Credit

\begin{abstract}
Abstrak
Artikel ini memiliki pokok masalah tentang penyebab perbankan belum memperbolehkan Hak Cipta sebagai Jaminan Fidusia dalam Transaksi Kredit Perbankan di Indonesia. Selain itu artikel ini bertujuan untuk mengetahui solusi yang harus dilakukan agar Hak Cipta dapat menjadi Jaminan Fidusia. Artikel ini adalah penelitian hukum empiris dan memiliki sifat deskriptif. Jenis data yang digunakan yaitu primer dan sekunder. Teknik pengumpulan data yang digunakan adalah wawancara dan studi kepustakaan, selanjutnya teknis analisis yang digunakan adalah metode deduktif. Hasil penelitian menunjukkan bahwa ada beberapa hal yang menyebabkan hak cipta sebagai jaminan fidusia dalam transaksi kredit perbankan belum diperbolehkan oleh bank. Penyebab yang pertama adalah kendala regulasi , kendala penilaian hak kekayaan intelektual seperti hak cipta, kendala menurut perbankan, kendala menurut OJK, kendala penilaian masyarakat terhadap hak cipta. Dari berbagai penyebab tersebut, penulis juga memaparkan solusi-solusi mengatasi penyebab tersebut agar ada titik terang atas Problematika Hak Cipta sebagai Jaminan Fidusia dalam Transaksi Kredit Perbankan.
\end{abstract}

Kata Kunci: Hak Cipta; Jaminan Fidusia; Kredit Perbankan

\section{A. Pendahuluan}

Hak cipta adalah istilah hukum untuk memberikan nama kreasi atau karya cipta manusia dalam bidang ilmu pengetahuan, sastra, dan seni. Istiiah ini merupakan sebuah terjemahan dari istilah dalam Bahasa Inggris yaitu copyright dan dalam Bahasa Belanda adalah auteurrecht. Para pihak yang terkait langsung dengan hak cipta yaitu kaum ilmuwan, sastrawan, dan seniman. (M. Syamsudin, 2001: 124). Hak cipta terdiri dari hak ekonomi (economic rights) dan hak moral (moral rights). Hak cipta menjadi salah satu bagian dari kekayaan intelektual. Sebuah pengakuan akan hak cipta sebagai objek pembebanan fidusia tidak terlepas dari teori hukum alam yang menghormati dan menghargai setiap karya intelektual seseorang. (Sudja na, 2012: 411). 
Perkembangan ekonomi kreatif dan berkembang pesatnya teknologi informasi serta komunikasi menjadikan Indonesia dan berbagai negara lainnya mengharuskan melakukan pembaruan UndangUndang Hak Cipta. (Muhammad Yuris Azmi, Hernawan Hadi, Moch. Najib Imanullah, 2016: 98). Secara berturut-turut pembaharuan Undang-Undang tentang Hak Cipta yaitu Undang-Undang Nomor 6 Tahun 1982 , Undang-Undang Nomor 7 Tahun 1987, Undang-Undang Nomor 12 Tahun 1997, Undang-Undang Nomor 19 Tahun 2002, Undang-Undang Nomor 28 Tahun 2014. UndangUndang No 28 tahun 2014 tentang Hak Cipta memberikan perlindungan hukum bagi pencipta karya cipta. Hak cipta dapat dijadikan sebagai objek jaminan fidusia. Ketentuan mengenai hak cipta dapat dijadikan sebagai jaminan fidusia tertuang dalam Pasal 16 Ayat 3 Undang-Undang No 28 Tahun 2014 tentang Hak Cipta. Dalam Bahasa Indonesia, fidusia merupakan istilah yang sudah lama dikenal. Dalam dunia hukum istilah fidusia juga sudah menjadi istilah resmi. Fidusia dalam Bahasa Indonesia juga dapat disebut "penyerahan hak milik secara kepercayaan". Dalam terminology Bahasa Belandanya sering disebut dengan istilah lengkapnya yaitu fiduciare eigendom overdracht, sedangkan dalam Bahasa Inggris secara lengkap sering disebut dengan fiduciary transfer of ownership. (Munir Fuady, 2013:101). Hal semacam ini menegaskan bahwa hak cipta sekarang ini memiliki manfaat bagi pencipta karya cipta karena dengan hasil ciptaan dapat digunakan sebagai jaminan dalam memperoleh kredit perbankan. (Rindia Fanny Kusumaningtyas,2016: 97).

Problematika yang terjadi saat ini adalah Undang-Undang Nomor 28 Tahun 2014 tentang Hak Cipta memperbolehkan bahwa hak cipta dapat dijadikan sebagai jaminan fidusia dan Undang-Undang Nomor 42 Tahun 1999 tentang Jaminan Fidusia juga menjelaskan bahwa objek jaminan fidusia itu dapat dalam bentuk tidak berwujud hal ini tidak membuat bank konvensional ataupun syariah di Indonesia menerapkan sebuah kredit dengan jaminan fidusia dalam bentuk hak cipta. Berdasarkan latar belakang tersebut sehingga penulis ingin membahas mengenai penyebab perbankan belum memperbolehkan hak cipta sebagai jaminan fidusia dalam transaksi kredit perbankan dan membahas solusi dalam menangani problematika tersebut.

\section{B. Metode Penelitian}

Penelitian ini menggunakan jenis penelitian hukum empiris. Sifat dari penelitian ini adalah bersifat deskriptif. Pendekatan dalam penelitian tipe ini adalah pendekatan sosio-legal (socio legal approach). Pada penelitian hukum empiris ini data yang diperoleh penulis digolongkan menjadi dua macam yaitu data primer dan data sekunder. Data primer yang digunakan dalam penelitian ini dengan cara wawancara. Data sekunder yang digunakan dalam penelitian ini dengan cara studi kepustakaan. Teknik yang diterapkan dalam melakukan penelitian ini adalah dengan mendeskripsikan data-data yang terkumpul dari data primer dan sekunder.

\section{Hasil Penelitian dan Pembahasan}

Problematika perbankan belum menerapkan hak cipta sebagai jaminan fidusia dalam transaksi kredit perbankan seperti yang diamanatkan Pasal 16 Ayat (3) Undang-Undang Nomor 28 Tahun 2014 tentang Hak Cipta ada beberapa hal yang menjadi penyebab. Penyebab-penyebabnya sebagai berikut:

1. Kendala Regulasi

Penyebab utama yang mendasari perbankan tidak menjadikan hak cipta sebagai jaminan fidusia dalam transaksi kredit perbankan adalah berkaitan regulasinya yang dirasa belum cukup memberikan pedoman bagi bank dalam menjadikan hak cipta sebagai jaminan fidusia dalam transaksi kredit perbankan. Dalam Penjelasan Pasal 16

Ayat (3) Undang-Undang Nomor 28 Tahun 2014 tentang Hak Cipta dikatakan bahwa "Cukup Jelas". Pada kenyataan yang terjadi ketentuan dalam Pasal 16 Ayat (3) UndangUndang Nomor 28 Tahun 2014 tentang Hak Cipta ini belum cukup jelas sehingga mengakibatkan perbankan sulit dalam melakukan penerapan. 
Bank Mandiri di Surabaya, Bank Negara Indonesia (BNI) di Sukoharjo, dan Bank Negara Indonesia (BNI) Syariah di Surakarta, ketiganya menerangkan hal yang sama bahwa regulasi yang sudah ada terkait hak cipta sebagai jaminan fidusia dalam Undang-Undang Nomor 28 Tahun 2014 tentang Hak Cipta ini belum cukup untuk memberikan pedoman secara utuh kepada bank dalam teknis penerapan hak cipta sebagai jaminan fidusia dalam transaksi kredit perbankan. Masih banyak hal yang perlu diatur dalam regulasi yang lebih teknis dalam penerapan hak cipta sebagai jaminan fidusia dalam transaksi kredit perbankan seperti penilaian (appraisal) dari hak cipta sendiri yang belum jelas tolak ukurnya maupun lembaga yang ditugaskan untuk menilai hak cipta sebagai jaminan.

\section{Penilaian Properti (Appraisal)}

Mekanisme penilaian benda yang akan dijadikan jaminan dan dibebani dengan lembaga penjaminan pada umumnya lembaga keuangan pemberi kredit (kreditur) menggunakan jasa penilai publik yang lazim disebut appraisal. Profesi Penilai Publik ini diatur dengan Peraturan Menteri Keuangan Republik Indonesia Nomor 101/PMK.01/2014 tentang penilai publik. Dalam peraturan tersebut dijelaskan bahwa penilai adalah seseorang yang memiliki kompetensi dalam melakukan kegiatan penilaian, yang sekurang-kurangnya telah lulus pendidikan awal penilaian, dan penilai publik telah memperoleh izin dari Menteri untuk memberikan jasa sebagaimana diatur dalam Peraturan Menteri tersebut. Menurut ketentuan 15 /PBI/2012 tentang Penilaian Kualitas Aset Bank Umum pada Pasal 43 bahwa agunan yang dapat diperhitungkan ditetapkan yaitu surat berharga dan saham yang aktif diperdagangkan di bursa efek di Indonesia atau memiliki peringkat investasi dan diikat secara gadai, tanah, gedung, dan rumah tinggal yang diikat dengan hak tanggungan, mesin yang merupakan satu kesatuan dengan tanah yang diikat dengan hak tanggungan, pesawat udara atau kapal laut dengan ukuran di atas 20 (dua puluh) meter kubik yang diikat dengan hipotek, kendaraan bermotor dan persediaan yang diikat secara fidusia; dan/atau, resi gudang yang diikat dengan hak jaminan atas resi gudang. Hak Cipta merupakan benda tidak berwujud (intangible asset), dalam akuntansi disebut sebagai aktiva tak berwujud, dimana aktiva tak berwujud merupakan non-monetary asset yang tidak memiliki wujud fisik yang terdapat dalam neraca perusahaan, yang digunakan untuk memproduksi barang dan jasa. Sertifikat Hak Kekayaan Intelektual saat ini belum termasuk dalam daftar agunan yang dimaksud oleh Bank Indonesia. Selain belum tercantum dalam daftar agunan, untuk hak cipta sampai saat ini belum ada pedoman penilaian yang dapat digunakan oleh penilai publik, sehingga tentu saja belum ada lembaga keuangan yang menerima hak cipta sebagai jaminan. (Reni Budi Setianingrum, 2016: 231).

\section{Bank}

\section{a) Standar Operasional Prosedur (SOP) Bank}

Standar Operasional Prosedur (SOP) menurut Soemohadiwidjojo merupakan panduan yang digunakan untuk memastikan kegiatan operasional organisasi atau perusahaan berjalan dengan lancar. (Satrio Gozal,2017:70). Bank Mandiri di Surabaya, Bank Negara Indonesia (BNI) di Sukoharjo, Bank Negara Indonesia (BNI) Syariah di Surakarta mempunyai SOP yang telah ditetapkan dalam menunjang kinerja keseharian, menjaga stabilitas bank, serta menjauhkan bank dari berbagai risiko yang dapat terjadi. Menjadikan Hak Cipta sebagai Jaminan Fidusia merupakan hal yang tidak sejalan dengan SOP yang telah diterapkan pada ketiga bank tersebut. Dalam pemberian kredit perbankan tentu bank-bank ini menjalankan kinerjanya seturut SOP dengan maksud untuk mengurangi kemungkinan buruk yang terjadi dan dampak yang tidak diinginkan. SOP bank diadakan dengan maksud untuk selalu menjaga kinerja bank, menjaga stabilitas bank, serta menjauhkan bank dari berbagai risiko yang dapat terjadi. Menjadikan hak cipta sebagai jaminan fidusia dalam transaksi kredit perbankan ini sendiri memiliki risiko yang tinggi. Pertimbangan risiko yang tinggi menyebabkan bank belum menerapkan hak cipta sebagai jaminan fidusia dalam transaksi kredit perbankan. (Trisadini P Usanti, 
Abd Shomad,2017:150). Dalam memberikan kredit, bank menentukan adanya jaminan dalam mitigasi risiko kegiatan transaksi kredit perbankan. Mitigasi kredit adalah suatu upaya untuk meminimalkan konsekuensi yang dapat ditimbulkan dari pemberian kredit yang dilakukan oleh bank kepada nasabah. Jaminan Kredit harus memiliki suatu nilai dan tugas bank adalah menilai jaminan yang diberikan oleh debitur memenuhi kelayakan sebagai suatu jaminan. Jaminan yang dikehendaki bank adalah jaminan yang mempunyai nilai ekonomi yang dapat memberikan keamanan bagi bank sehingga tidak menimbulkan kerugian jika terjadi wanprestasi.

b) Persepsi Bank

Dalam menanggapi tidak diperbolehkannya hak cipta sebagai jaminan fidusia dalam transaksi kredit perbankan di Indonesia, Bank Mandiri di Surabaya, Bank Negara Indonesia (BNI) di Sukoharjo, Bank Negara Indonesia (BNI) Syariah di Surakarta ini memberikan berbagai persepsi. Bank Negara Indonesia (BNI) Syariah di Surakarta menyebutkan bahwa jaminan itu sendiri dibagi menjadi dua. Pertama yaitu kemampuan nasabah dalam membayar kreditnya dan juga komitmen nasabah dalam membayar kreditnya. Kedua yaitu jaminan yang berbentuk barang yang berwujud seperti mobil ataupun tanah maupun surat berharga. Bank Negara Indonesia Syariah di Surakarta ini sendiri menitikberatkan kredit pada sebuah kemampuan dan komitmen dari nasabahnya sendiri, jaminan kedua seperti barang yang berwujud ataupun surat berharga sendiri menjadi alternative jika sebuah kepercayaan bank akan kemampuan dan komitmen nasabah sudah tidak berjalan dengan baik. Jaminan Kedua ini diadakan demi keamanan dari bank dalam menyalurkan dana (kredit) kepada nasabahnya. Bank dalam menentukan barang barang apa saja yang dapat dijadikan sebagai Jaminan Hak Tanggungan maupun Fidusia adalah barang barang yang dapat dilelang, dijual, maupun dicairkan dengan mudah jika terjadi wanprestasi. Kendala yang dihadapi Bank Negara Indonesia Syariah di Surakarta sehingga tidak menerapkan hak cipta sebagai jaminan fidusia adalah dengan belum jelasnya penilaian secara ekonomi terhadap hak cipta sebagai sebuah jaminan. Bank hingga saat ini tetap bepegang teguh bahwa yang dijadikan sebagai jaminan adalah yang jika terjadi sebuah wanprestasi tindaklanjutnya atas wanprestasi itu mudah dengan jaminan yang mudah dikelola (dilelang, dijual, ataupun dicairkan). Namun tidak memungkiri bahwa jika seorang nasabah mengajukan permintaan kredit dengan Jaminan Fidusia Hak Cipta bisa namun dengan pertimbangan lain seperti tentang kemampuan seorang nasabah dan komitmen yang dapat membuat bank percaya utuh dengan nasabah tersebut. Jadi saat ini kemungkinan diperbolehkannya Hak Cipta sebagai Jaminan Fidusia itu bukan karena pandangan bank mengenai jaminan tersebut terlebih karena alasan pertama yang paling penting dalam kredit menurut bank adalah pandangan bank terhadap kemampuan dan komitmen nasabahnya. Bank Negara Indonesia Syariah di Surakarta belum mengetahui cara pengelolaan dan penilaian sebuah hak cipta dalam perannya sebagai jaminan fidusia dalam transaksi kredit perbankan. Bank Negara Indonesia Syariah di Surakarta mengharapkan ke depannya Otoritas Jasa Keuangan dapat membuat regulasi yang bisa mendukung Undang-Undang Nomor 28 Tahun 2014 tentang Hak Cipta sehingga pelaksanaannya dapat jelas untuk ke depannya. Hak Cipta yang dapat dijadikan Jaminan Fidusia tentu akan menarik banyak nasabah untuk kredit di bank namun jika memang sudah dengan adanya payung hukum yang cukup jelas. Bank konventional seperti Bank Mandiri di Surabaya dan Bank Negara Indonesia (BNI) di Sukoharjo pun memiliki persepsi sendiri. Bank Mandiri di Surabaya tidak pernah mengetahui bahwa sebuah Hak Cipta dapat dijadikan sebagai Jaminan Fidusia dalam Transaksi Kredit Perbankan.

Bank Mandiri di Surabaya tidak pernah sama sekali mendudukkan sebuah hak cipta dapat diproses menjadi sebuah jaminan fidusia dalam kredit perbankan. Bank Mandiri di Surabaya ini merasa belum ada peraturan perundang-undangan yang secara 
jelas mewajibkan bank-bank konventional ataupun syariah dalam menjadikan hak cipta sebagai jaminan fidusia dalam kredit perbankan. Meskipun di dalam UndangUndang tentang Hak Cipta sudah ada namun pihaknya merasa belum cukup jelas dalam memberikan pedoman bank untuk bisa menjalankan kredit dengan jaminan sebuah hak cipta. Otoritas Jasa Keuangan sekalipun belum mengeluarkan Peraturan Otoritas Jasa Keungan (POJK) terkait hak cipta yang dijadikan sebagai jaminan fidusia dalam transaksi kredit perbankan. Bank Mandiri di Surabaya menjelaskan bahwa kendala hak cipta yang dijadikan sebagai jaminan fidusia adalah sulitnya eksekusi jika ada kredit macet yang terjadi dalam kredit perbankan. Bank Mandiri di Surabaya ini lebih memilih jaminan-jaminan yang mengandung SHM ataupun SHGB yang dirasa lebih mudah untuk diekseskusi penyelesaian apabila terjadi kredit macet. Bank Negara Indonesia di Sukoharjo menjelaskan bahwa pihaknya sama sekali tidak mengetahui adanya jaminan kredit perbankan dalam bentuk jaminan fidusia berupa hak cipta. Bank Negara Indonesia di Sukoharjo juga merasa kedudukan khusus mengenai hak cipta sebagai jaminan fidusia dalam transaksi kredit ini memang belum ada. Bank Negara Indonesia di Sukoharjo ini sendiri berpendapat terkait hak cipta yang dijadikan sebagai jaminan fidusia dalam transaksi kredit bahwa hal tersebut sebetulnya baik diterapkan dalam dunia perbankan. Dengan adanya hak cipta yang dapat dijadikan sebagai jaminan fidusia dalam transaksi kredit perbankan ini dapat mempermudah para pencipta-pencipta karya yang ada di Indonesia dalam pengajuan kredit perbankan. Bank Negara Indonesia di Sukoharjo ini juga menjelaskan dimungkinkan Undang- Undang Nomor 8 Tahun 2010 tentang Hak Cipta yang menerangkan Hak Cipta dapat dijadikan sebagai jaminan fidusia memang dikhususkan pemerintah untuk mempermudah para pencipta -pencipta karya terkhusus di kota k ota besar di Indonesia dalam pengajuan kredit. Namun menurut pendapat dari pihak Bank Negara Indonesia di Sukoharjo ini sendiri, baginya hak cipta sebagai jaminan fidusia dalam transaksi kredit perbankan ini kurang cocok bila di tempatkan atau diberi kedudukan di kota kota kecil karena memang liquiditas tidak tinggi jadi dinilai cukup berat untuk diterapkan. Liquiditas tidak tinggi ini membuat mitigasi risiko dalam ruang lingkup kredit perbankan juga menjadi rendah. Bank Negara Indonesia di Sukoharjo ini merasa mempunyai risiko yang terlalu tinggi untuk menjadikan hak cipta sebagai jaminan fidusia dalam transaksi kredit perbankan. Bank Negara Indonesia di Sukoharjo menjelaskan bahwa hal yang dalam sistem perbankannya belum menerapkan jaminan fidusia dalam transaksi kredit perbankan berupa hak cipta ini oleh sebab belum ada akses kearah sana, jarang sekali ada pencipta pencipta karya dalam hal ini calon debitur yang memiliki nilai untuk penjaminan hak cipta. Yang dapat dijadikan sebagai jaminan kredit fidusia di Bank Negara Indonesia di Sukoharjo ini yaitu berupa BPKB (Bukti Kepemilikan Kendaraan Bermotor). Bank Negara Indonesia di Sukoharjo ini sendiri berpandangan bahwa kendala terletak dari jangkauan pasar yang dinilai sempit. Menjadikan hak cipta sebagai jaminan fidusia dalam transaksi kredit ini sendiri hanya dapat menjangkau debitur-debitur pencipta-pencipta karya saja yang mana juga tidak semua pencipta-pencipta karya di Indonesia ini mendaftarkan karyanya supaya memiliki hak cipta atas karyanya secara resmi dari negara. Selain itu, menurut Bank Negara Indonesia di Sukoharjo jika hak cipta sebagai jaminan fidusia dalam transaksi kredit perbankan ini diterapkan akan menyulitkan bank sendiri dengan kendala apabila terjadi kredit macet bank akan sulit menjual hak cipta itu sendiri karena berharganya sebuah hak cipta bagi masing-masing orang tentu akan berbeda. Jadi akan sulit sekali untuk mendapatkan calon pembeli hak cipta yang telah dijadikan jaminan kredit macet tersebut. Bank Negara Indonesia di Sukoharjo ini sendiri juga menjelaskan penilaian hak cipta akan semakin berharga dan mahal apabila karya ciptanya unik namun kembali perlu disadari kembali pada zaman sekarang ini banyak sekali orang yang cepat sekali berinovasi untuk menciptakan sebuah karya yang lebih unik dan lebih unik lagi sehingga juga dapat menurunkan nilai hak cipta sebelumnya. Penilaian hak cipta itu sendiri 
mempengaruhi kepercayaan bank dalam memberikan kredit perbankan dengan jaminan hak cipta.

Dari persepsi bank konvensional dan bank Syariah di Indonesia yang penulis jadikan sebagai tempat penelitian, dapat dikatakan bahwa masalah utamanya adalah masalah sosialisasi peraturan perundang undangan. Meskipun Undang -Undang Nomor 28 Tahun 2014 tentang Hak Cipta sudah lama diberlakukan dan dipublikasikan tidak menjadikan keberadaan Undang-Undang ini diketahui banyak pihak terutama pihak penyedia jasa keuangan seperti bank yang berkaitan langsung dengan peraturan ini. Faktanya hingga saat ini bank konvensional dan bank Syariah tidak mengetahui adanya aturan yang memperbolehkan hak cipta sebagai jaminan fidusia dalam transaksi kredit perbankan. Jika sosialisasi pemerintah tidak rendah akan membuat banyak pihak mengetahui mengenai jaminan fidusia dalam bentuk hak cipta dalam dunia perbankan. Eksistensi yang tinggi dapat membuat penyedia jasa keuangan khususnya Bank dan Otoritas Jasa Keuangan (OJK) juga dapat berkembang dengan mulai memikirkan penilaian hak cipta dan ketentuan ketentuan lanjutan yang dapat diterapkan untuk melaksanakan hak cipta sebagai jaminan fidusia dalam transaksi kredit perbankan.

4. Otoritas Jasa Keuangan (OJK)

Menurut pendapat Bank Mandiri di Surabaya, Bank Negara Indonesia di Sukoharjo, dan Bank Negara Indonesia Syariah di Surakarta dalam merealisasikan Hak Cipta sebagai Jaminan Fidusia dalam Transaksi Kredit Perbankan adalah diperlukan peraturan yang lebih teknis dari OJK. Namun persepsi Otoritas Jasa Keuangan di Surakarta adalah Bank belum memperbolehkan hak cipta sebagai jaminan fidusia dalam transaksi kredit perbankan oleh karena tolak ukur dalam menilai suatu hak cipta sebagai jaminan fidusia itu belum ada. Bank dalam melakukan kegiatan transaksi kredit tentu membutuhkan agunan yang dapat menjamin keamanan bank dalam memberikan kredit perbankan. Menurut OJK dalam penilaian ini merupakan tugas dari Direktorat Jenderal Kekayaan Intelektual dalam membuat penilaian dan menunjuk Lembaga tertentu untuk mengaturnya. OJK mengatakan bahwa OJK memang memiliki tugas dalam membuat regulasi dalam bentuk POJK (Peraturan Otoritas Jasa Keuangan) namun baginya sebelum OJK membuat POJK dibutuhkan aturan yang lebih teknis terutama terkait penilaian dari Direktorat Jenderal Kekayaan Intelektual agar OJK memiliki aturan yang dapat dijadikan acuan OJK dalam membuat POJK.

\section{Penghargaan Masyarakat Indonesia terhadap Hak Cipta}

Suatu karya cipta/ciptaan dapat dijadikan sebagai objek jaminan fidusia karena hak cipta merupakan bagian dari kekayaan intelektual yang dalam kekayaan intelektual yaitu meliputi hak kebendaan dan hak milik. Sebuah pengakuan akan hak cipta sebagai objek pembebanan fidusia tidak terlepas dari teori hukum alam yang menghormati dan menghargai setiap karya intelektual seseorang. Penghargaan itu diberikan begitu dikarenakan ciptaan tersebut merupakan kekayaan hasil olah pikir intelektual yang mengandung nilai ekonomi sehingga dapat dijadikan objek jaminan. (Sudjana, 2012: 411). Di Indonesia penghargaan terhadap Hak Cipta masih rendah. Masyarakat Indonesia yang memberikan penghargaan yang rendah terhadap hak cipta ini dapat menyebabkan hak cipta sebagai jaminan fidusia dalam transaksi kredit perbankan di Indonesia sulit direalisasikan.

Berbagai penyebab telah menghambat proses dalam menerapkan hak cipta sebagai jaminan fidusia dalam transaksi kredit perbankan. Maka diperlukan berbagai upaya untuk dapat memberikan solusi atas adanya hambatan hambatan yang menghalangi hak cipta dapat dijadikan sebagai jaminan fidusia dalam transaksi kredit perbankan di Indonesia. Upaya upaya tersebut diantaranya yaitu upaya pembuatan regulasi berupa Peraturan Pemerintah (PP) Penilaian Hak Cipta dapat menggunakan 3 pedoman penilaian yang mendasar yaitu Penilaian Berbasis Biaya yaitu penilaian yang mempertimbangkan besaran biaya dalam proses membuat hak cipta 
secara historis dan besaran biaya dalam proses membuatnya kembali mengingat tarif saat ini, Penilaian Berbasis Pasar yaitu penilaian yang mempertimbangkan transaksi pasar yang sebanding, penjualan atau pembelian dari hak cipta, Penilaian Berbasis Pendapatan yaitu penilaian yang mempertimbangkan aliran pendapatan yang dapat dikaitkan dengan hak cipta berdasarkan pada pendapatan historis dan pendapatan yang diharapkan di masa depan. Dalam Peraturan Pemerintah (PP) juga dibutuhkan untuk dicantumkan ketentuan pemberian mandat kepada Otoritas Jasa Keuangan dalam menentukan pendaftaran penilai publik dan menentukan besaran batas kredit perbankan yang menggunakan jaminan berupa hak cipta, sehingga Otoritas Jasa Keuanganpun memiliki tugas yang jelas terkait pembuatan Peraturan Jasa Keuangan. Selain itu, dibutuhkan perbaikan perjanjian kredit perbankan yang mana setiap perjanjian kredit perlu dicantumkan secara jelas penilaian hak cipta sebagai jaminan. Upaya terakhir yang dapat dilakukan juga dapat melakukan sosialisasi peraturan perundang-undangan hak cipta sebagai jaminan fidusia. Eksistensi Hak Cipta yang dapat dijadikan sebagai jaminan fidusia dalam transaksi kredit perbankan di khalayak masyarakat Indonesia dapat mempengaruhi permintaan pasar akan kredit dengan jaminan fidusia berupa hak cipta. Permintaan pasar yang tinggi akan mendorong pemerintah untuk dapat segera memperbaharui regulasi terkait hak cipta yang dijadikan sebagai jaminan fidusia dalam transaksi kredit perbankan.

\section{Simpulan}

Berbagai macam problematika yang menyebabkan perbankan belum memperbolehkan hak cipta sebagai jaminan fidusia dalam transaksi kredit perbankan. Penyebab-penyebab itu di antaranya adalah kendala regulasi, kendala penilaian property hak kekayaan intelektual seperti hak cipta, kendala SOP perbankan dan persepsi perbankan, persepsi Otoritas Jasa Keuangan, dan juga kendala penghargaan masyarakat Indonesia terhadap hak cipta. Dari beberapa macam kendala tersebut penulis menemukan beberapa upaya yang dapat dilakukan sebagai solusi menangani problematika hak cipta sebagai jaminan fidusia dalam transaksi kredit perbankan di Indonesia. Solusi-solusi atas problematika tersebut di antaranya adalah membuat peraturan yang lebih teknis seperti Peraturan Pemerintah (PP) dan Peraturan Otoritas Jasa Keuangan (POJK). Peraturan Pemerintah (PP) yang mengatur terkait pedoman penilaian hak cipta, Lembaga penilai, jenis hak cipta yang dapat dijadikan sebagai jaminan fidusia, mitigasi risiko yang dapat dilakukan perbankan jika mengalami wanprestasi pada kredit perbankan dengan jaminan hak cipta. Selain membuat peraturan yang lebih teknis dibutuhkan perbaikan perjanjian kredit perbankan dan sosialisasi peraturan perundang-undangan hak cipta sebagai jaminan fidusia.

\section{E. Saran}

Upaya merealisasikan hak cipta sebagai jaminan fidusia dalam transaksi kredit perbankan di Indonesia hendaknya pemerintah segera membuat Peraturan Pemerintah (PP) yang mengatur terkait pedoman penilaian hak cipta, Lembaga penilai, jenis hak cipta yang dapat dijadikan sebagai jaminan fidusia, mitigasi risiko yang dapat dilakukan perbankan jika mengalami wanprestasi pada kredit perbankan dengan jaminan hak cipta. Selain itu, Peraturan Pemerintah perlu memberikan mandat kepada Otoritas Jasa Keuangan dalam menentukan pendaftaran penilai publik dan menentukan besaran batas kredit perbankan yang menggunakan jaminan berupa hak cipta sehingga Otoritas Jasa Keuanganpun memiliki tugas yang jelas terkait pembuatan Peraturan Jasa Keuangan.

\section{F. Daftar Pustaka}

Buku :

Trisadini P Usanti dan Abd Shomad. 2017. Hukum Perbankan. Depok: Penerbit Kencana. Munir Fuady. 2013. Hukum Jaminan Utang. Jakarta: Penerbit Erlangga. 


\section{Jurnal :}

M. Syamsudin. 2001. "Nilai-nilai Karya Cipta dan Problematik Perlindungan Hukumnya". Jurnal Hukum. Volume 8. Nomor 16. Maret 2001. Yogyakarta: Universitas Islam Indonesia.

Muhammad Yuris Azmi, Hernawan Hadi, Moch. Najib Imanullah. 2016. "Hak Cipta Sebagai Jaminan Fidusia Ditinjau dari Undang-Undang Nomor 28 Tahun 2014. Tentang Hak Cipta dan UndangUndang Nomor 49 Tahun 1999 tentang Jaminan Fidusia". Privat Law. Volume 4 Nomor 1, Juni 2016. Surakarta: Universitas Sebelas Maret.

Reni Budi Setianingrum. 2016. "Mekanisme Penentuan Nilai Ekonomis dan Pengikatan Hak Cipta Sebagai Objek Jaminan Fidusia". Jurnal Media Hukum. Volume 23 Nomor 2, Desember 2016. Yogyakarta: Universitas Muhammadiyah Yogyakarta.

Rindia Fanny Kusumaningtyas. 2016. "Perkembangan Hukum Jaminan Fidusia Berkaitan dengan Hak Cipta sebagai Objek Jaminan Fidusia". Pandecta: Fakultas Hukum Universitas Negeri Semarang. Volume 11 Nomor 1, Juni 2016. Semarang: Universitas Negeri Semarang.

Satrio Gozal. 2017. "Perancangan Standar Operasional Prosedur Siklus Operasional pada Perusahaan Stagger Media". Performa Jurnal Manajemen dan Start-Up Bisnis. Volume 2 Nomor 1, April 2017. Surabaya: Universitas Ciputra.

Sudjana. 2012."Hak Cipta Sebagai Jaminan Kebendaan Bergerak Dikaitkan dengan Pengembangan Objek Fidusia". Mimbar Hukum. Volume 23 Nomor 3, Oktober 2012. Yogyakarta: Universitas Gajah Mada. 